\title{
Study on the Cucumber Mosaic Virus (CMV) Transmission by Whitefly Insect (Order: Homoptera; Family: Aleurodidae; Bemesia tabaci) to Broad Bean Plant(Vicia fabae) with Some Physical and Natural Properties of the Virus in the Laboratory
}

\author{
Gazala .I.F.Saad, Mariam Saleh Mohamad, Othman.B.H.AL-Daikh.
}

\begin{abstract}
This study was conducted in the Plant Protection Department - Agriculture College - Omar AL-Mukhtar University, during the period from June to December, in order to know how the plant virus mechanically transmitted and through the feeding process of the white fly insect during the season 2017-2018 as well as the bioassay on The study of virus infection symptoms on the broad bean plants.

Using white fly has been shown from the experiment after the infection that the thermal degree of the virus temperature was $\left(45^{\circ}\right)$ and the final point of dilution $\left(10^{-3}-10^{-} 7\right)$ and the duration of the continuity of the virus activity in the filtrate was (40) days. The results of this study indicated that the virus is transferred efficiently from infected plants to healthy one by white fly and 5 insects were enough to transport the virus by $25 \%$ and the ratio increased by increasing the number of insects on the plant reaching $75 \%$ When using 10 insects per plants. The minimum time required to feed the white fly insect on the infected plant leaves for 30 minutes and the same time for the virus- carried by insect to the plant to be infected. The results of this study as well as showed that the blight and yellowing mosaic symptoms on the leaves of the broad beans (growing in the green houses). After 3 - 7 days of the infection, In CMV virus derived from mechanical transmisston the symptoms on bean plants appeared as ideal marked by the appearance of pale and yellowing of the light and wrap on the leaves and general weakness on the plants as well as the minimum period of insect feeding after an hour from inoculation the rate of virus transferred was $11.1 \%( \pm 0.0)$, the average percentage of transmission $11.1 \% \pm 7.0$ The incubation period of the virus in the body of the insect was $\mathbf{2 4}$ hours. Increasing the feeding time of the insect on the infected and healthy plant increases its efficiency to transmitting the virus.
\end{abstract}

Index Terms-Virus CMV, White fly insect, disease management.

\section{INTRODUCTION}

The beans are the major legume crops which grown in irrigated and rainfed, native to Western Asia and North Africa. Chavan ,1989 said that, It is one of the most important legume crops and belongs to the family fabiaceae. It has been known by China since 2800 BC, as well as in Europe (in Italy, France and Spain) and has been since cultivated and moved

Gazala I. F. Saad Plant Protection Department- Faculty of Agriculture- Omar AL-Moktar University, El-Beida, Libya

Mariam Saleh Mohamad Plant Protection Department- Faculty of Agriculture- Omar AL-Moktar University, El-Beida, Libya

Othman. B.H.AL-Daikh Plant Protection Department- Faculty of Agriculture- Omar AL-Moktar University, El-Beida, Libya from Europe to North America. The beans is a cheap source of vegetable protein for high percentage of the population all over the world, especially the Third World countries. Total area under bean cultivation in Libya was about 10.000 hectares. It is grown in different parts of Libya as an important food crop for human consumption. It is also contains a high percentage of carbohydrates, many vitamins, nutrients, nutritional salts, essential amino acids for humans and animals, as well as its ability to stabilize atmosphere weather,nitrogen fixation, increasing soil fertility, in co-existence with root nodules and used as human food in developing countries. In addition to being used as animal feeding, the crop is infected with many viral diseases that cause crop damage between 5\% and 20\%. The most important of these viruses were the domestic bean carried virus, and the beans infected by the viruses by different ways.

Viruses are a key factor in reducing productivity in bean production Babovic , 2003. Relate to the amount of losses the virus type and its descendants and the age of the plant at the incidence of beans sensitivity and the damage depend on a particular viral disease as sensitive and susceptibility to injury plants, the stage of plant development where infections occur, environmental factors and their impact on the activity of disease vector soybean and broad bean ( Vicia faba L.) Petrovic et al ., 2010.

A scientific study revealed that the spread of white fly insects in various vegetable crops in June and December of each year. The spread of the insect was observed on cucumber, squash, pepper, tomato, beans and papaya in both greenhouses and open fields (Duffus , 1994. , Morales, 2004). This propagation is influenced by environmental factors, such as temperature, relative humidity and wind velocity, indicating a positive correlation between propagation rates and temperatures while there is less correlation with both wind velocity and humidity. White fly insects transmit some viruses to crop leaves, reducing the efficiency of photosynthesis, resulting in a clear reduction of the crop productivity. During the planting season of the year (2006), crop productivity is affected by a number of factors, including viruses (FAO) More than 40 viruses were recorded to influence the beans. Investigations revealed that the main virus problem in the bean crop (Makkouk et al ; El- Muadhidi et al .2001) The virus spreads showing blackness and yellowing of the bean leaves with high efficiency by the white fly.

Studies and research has shown that this virus can be transmitted mechanically, or by some insects with piercing 


\section{Study on the Cucumber Mosaic Virus (CMV) Transmission by Whitefly Insect (Order: Homoptera; Family: Aleurodidae; Bemesia tabaci) to Broad Bean Plant(Vicia fabae) with Some Physical and Natural Properties of the Virus in the Laboratory}

sucking mouth parts, especially aphids and white fly and some beetles, in addition to the possibility of being transferred by family Cucurbitaceae seeds, where the virus can move (Khalil Jaber, 1984). The objectives of this study are: the mechanical transmission of the disease and the identification of symptoms and the study of some physical and natural properties of the virus in the laboratory.

One insect can acquire the virus and transfer it to bean plants in a residual way. White flies also carry geminiviruses to many crops, causing significant importance crop losses ( Polston \& Anderson 1997). It was found that the duration of the insect on the infected plant to acquire the virus and the duration of the virus-carrying insect on the plant suitable for infection between 20-30 minutes and increase the efficiency of the insect to transport and to increase the length of acquisition and infection. Lapidot, et.al., 2001, Bird,et.al.2001 ,and Mehta, et.al, 1994,Indicated that the duration of Incubation of the virus in the body of the insect between 21-24 hours. Represents Cucumber mosaic virus ( Cucumoviridae). It is known that CMV Infect more than 1,200 species of plants including bean plant crops and other plants. A number of crops including beans decorations has been affected by important and significant problems in the green houses and in the open fields. ( Ismail, 2000) Is considered to be specific to the cultivation of this crop in Libya. So the study was conducted with the aim of determining the transmission of the whitefly, virus mechanically to bean plants and could represent a source of injury Beans and carrier identification and mode of transport. The white fly insect is a species B.tabaci .Many viral diseases (about 30 or more diseases during the process of feeding the nymph and whole insects on infected plants) are transmitted. The spread of infection from diseased wild plants to sensitive plants takes several minutes to several hours. The population dynamics of this pest are affected by different interactions Crops intertwined simultaneously or sequentially in any of the regions are associated with the effect of environmental factors of heat and humidity and white fly insects have the ability to transmit many pathogens to their plant families belonging to the groups

(Geminiviruses, Closteroviruses, Carlavirus, Nepoviruses) Hanson, et.al .2000, Robinstein, 1999, Wisl er, et.al .1998

White fly B. tabaci was observed In recent years on the cultivation of beans, causing direct damage to plants, where sucking the sap of plants and cause weakness, and show the honeydew on the leaves in the case of severe white fly injury (Liu, 2000). As it has been explained that the yellow spots appear in the place of feeding of insects that got piercing sucking mouth parts lead to deformation with modern Mosaic leaves infected and a lot of insects move to the crops early after the beans dried and removing neighboring cotton plants for the cultivation of beans And the early diagnosis of infection in this scourge is considered important in reducing the damage expected by mosaic symptoms of the impact of viruses on chloroplasts.

\section{MATERIALS AND METHODS}

Collection of infected plant samples2.1

Collected samples of infected cucumber leaves from the intermediate area and relied on the examination of the plants and recorded symptoms of infection and placed in plastic bags and recorded data and transferred to the laboratory in refrigerated boxes (Ice box).

The plants were planted in pots containing soil mixure .They were irrigated and kept under wooden cages covered with malleable cloth In the plastic greenhouse, the temperature was $25^{\circ} \mathrm{C}$ and the purpose of keeping the infected plants alive and insects putted a live to be used in experiments of mechanical transport or insect transport, respectively( Pappu, et.al .2000., Bird, et.al .2001).

.Study the effect of mosaic virus infection option on the bean plant2 2. The seeds of the bean plants were sterilized superficially by Sodium hypochlorite $20 \%$ for one minute and then washed with distilled water and dried on filter paper, planted in a mixture of sterile soil (1:1), and then putted in autoclave, at $121^{\circ} \mathrm{C}$ and pressure $1.5 \mathrm{~kg} / \mathrm{cm}^{2}$ for 30 minutes and repeated sterilization after 24 hours, in plastic bags. Plants were distributed after germination to one plant / pot and treated with insecticide and pesticide against the pests . Plants were kept in a plastic house in wooden cages covered with gauze to protect them from insects. The experiment was designed in a complete random way, CRD.

\section{INJECTION METHOD (INFECTION)}

Samples were collected from cucumber leaves showed the symptoms of mosaic and crushed with Buffer phosphate solution 0.01 Molar in mortar casserole, nominated extracted through two layers of gauze cloth and used the filtrate Inoculation for the virus and infected bean plants and adopted plants that showed mosaic symptoms as a source of virus and after the preparation of the vaccine for an industrial infection from the sap of infected leaves with virus, the process of mechanical transport was carried out by causing minor injuries to the leaves of the plants using some materials that cause wounds such as fine sand or sanding powder ( Carborandum). And then pass the vegetable sap taken from the plants infected with viruses on the surfaces of these sheets with a piece of gauze and then wash the leaves injected with water to get rid of the acidic effect of vegetable sap from the surface of injected leaves.

\section{STUDY THE RELATIONSHIP BETWEEN THE VIRUS AND THE INSECT}

-Transfer of the virus:

transfer of the virus by the white fly insect B. tabaci Gen. Large numbers of white fly insect collected from cucumber fields and some herbaceous plants were identified as insect $B$. tabaci In Plant Protection Department, Agriculture faculty, Omar AL- Mukhtar University. And the insects were transferred to a wooden cage of the size $90 \times 30 \times 50 \mathrm{~cm}$, containing bean plants, and the cage covered with two layers of cloth and has a class sound option plant. Is a carrier of any symptoms.appear plants inside a wooden cage coated cloth, gauze, the insect left feeding and the acquisition of the virus for a period of 24 hours , then transferred to a group revealing plants were placed in advance inside the wooden cages by 20 . For each insect three replicates per plant and insects left to feed for a period of 24 hours after the pesticide sprayed. Aleart Sc 36\% And at a rate of $0.2 \mathrm{ml} /$ liter, and then followed the emergence and development of symptoms on a daily basis. 
Smith, 2000 Collected numbers of the white fly from plants by eye dropper, insects were transferred to plants surrounded by a piece of cloth for breeding. A number of virus-free white flies were transferred to wooden cages, to infected plants and left fed for 24 hours to acquire the virus, then Transferring the insect-carrying virus to healthy plants and the insects were left.

Feeding on healthy plants for 24 hours . 10 insect / plant (then sprinkled with insecticide to exterminate).

Bean plants were left intact for comparison Control To ensure purity of virus isolation repeated the experiment in the following season

The collected samples were placed in a small plastic bottle paper from an aspirator . Non- perfluoric white flies, which were retained in the bottle and allowed to feed on cucumber plants for 24 hours in an insect-resistant cage ( Brown, et. al., 1995 ).

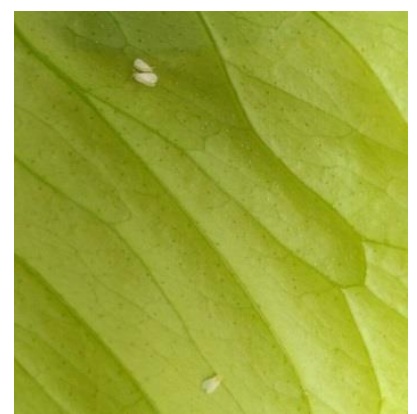

Figure (1): showed that the healthy leave of the plant.

The white flies were then moved to Seedlings of healthy beans for 48 hours. White flies were removed and plants kept in the growth chamber at 22 to $28^{\circ} \mathrm{C}$. Plants that appear pale yellow, were considered the source of the virus for this study.

\section{RESUltS}

Inoculation and mechanical symptoms. When infected leaves were used as a source of virus for the mechanical inoculation of the bean plant, the virus was easily transmitted to the plant and the bean seedlings were easily mechanically infected. Symptoms developed 4 to 5 days after Inoculation. Early symptoms were evident in recent times, and appeared on normal leaves usually after 3 to 7 days, and may last from 10 to 14 days or more for development on the affected host . Some times, it has been mechanically proven (Costa, 1986 ), This virus is considered as Comovirous by the sap,Duffus, JE 1994. The CMV has a wide family range especially on the legume family plants. Hassan, A.A, and Duffus , J.E, 1991.

And this was identical to what some scientists saw such as Francks , R 1985. The seriousness of the disease lies in the occurrence of deformities on the leaves in addition to the occurrence of dwarf and yellowing of leaves due to its effect on green plastids [ Reynolds, ES 1962 . ] Leading to a decrease in production quality and quantity have not conducted serological tests. This virus, which is necessary to identify the q uality of the virus and the conditions in the laboratory currently available to us, but this study may contribute to the identification of this virus and the identification of symptoms and paleness and yellowing leaves when beans are mechanically inoculated and used as a source of infection after the vaccination.
After 7 days of industrial infection appeared on the modern leaves of bean plants infected with extract virus, small pale areas evolved into two bean seedlings mosaic with varying degrees of injury is generally a pale yellowish light on the leaves as they are shown in (Fig.2) on the beans, while, There were no symptoms appear on control plants, and the Plants for disease observation.

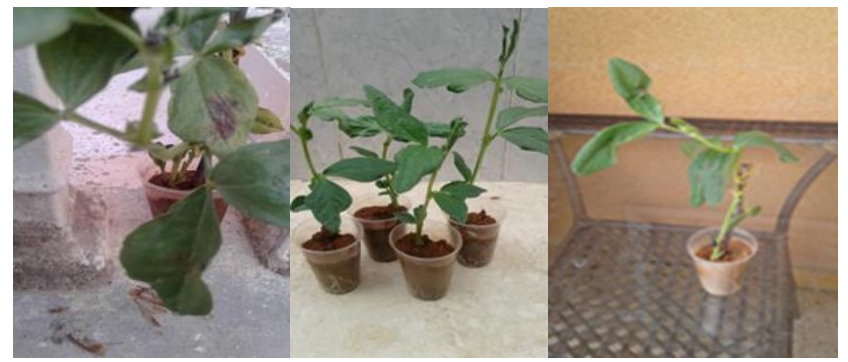

Fig. (2): Showed that the appearance of the mechanical symptom of disease Infection.

Transmission: The white fly were fed on the infected bean plants, and then transferred to the healthy plants. And after 5 days of the infection by the white fly, symptoms started to be appeared gradually by wrapping some leaves and pale and yellowing, While, plant weakness, by the virus affected plastids with the appearance of spots as green dim or yellow colour on the leaves, which exchange with the color of natural green leaves, For that appeared on the leaves spattered showed syndrome. The embossed on the leaves exploratory disease that observed by viral infection as in the figure below.
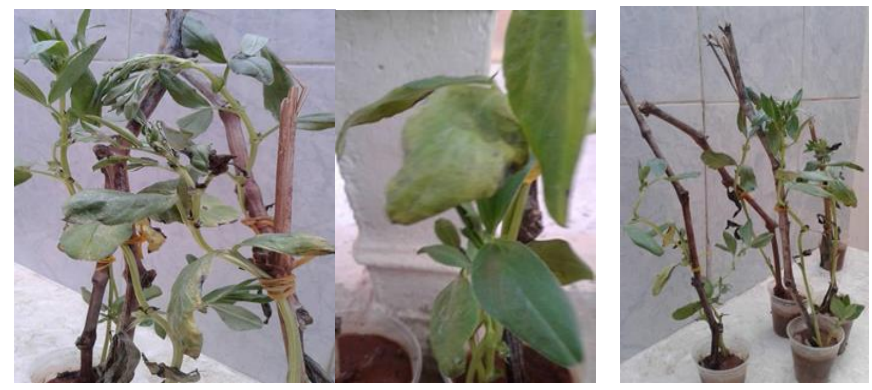

Fig. (3) showed that the emergence of symptoms after the process of infection by feeding the insects on the plants.

\section{Minimum feeding period acquisition}

Minimum feeding time for white flies To become contagious ( viruliferous ) was 1 hour after feeding periods of $1,6,10$ or 24 hours, the transfer rate was $11.1 \%( \pm 0.0), 27.8 \pm 6.4,69.4 \pm$ 5.5 and $94.4 \pm 6.4$ respectively. Values in parentheses, the standard deviation represents the minimum feeding period for transmission when white flies were fed to the source virus for 24 hours and then transferred to healthy seedlings for 1, 6, 10 or 24 hours, the mean percentage of the obtained calculation was $0 ., 9.5( \pm 5.0), 26.1( \pm 5.5)$, and $55.5( \pm 11.1)$, respectively. When white flies were fed only 1 hour on the source of the virus and then transferred to healthy plants for 1 , 6,10 or 24 hours, the mean transfer rate was $11.1 \pm 7.0,19.5 \pm$ $5.5,27.8 \pm 6.4,47.2( \pm 10.6)$, respectively. Observed transport efficiency of tanker, and the percentage of transport increase with increasing feeding time.

Vector relationships with the viruses had several formes. On one side, the link occurs inside the insect feeder, where the virus can be quickly absorbed and then released into a different plant cell. The nutrition bug loses the virus quickly 


\section{Study on the Cucumber Mosaic Virus (CMV) Transmission by Whitefly Insect (Order: Homoptera; Family: Aleurodidae; Bemesia tabaci) to Broad Bean Plant(Vicia fabae) with Some Physical and Natural Properties of the Virus in the Laboratory}

when it feeds on an uninfected plant ( Ramusi and Flett, 2012 ; Agrios , 2014 ). This relationship is called "non-fixed" ( Strange , 2003). The duration of the virus activity outside the host cells at room temperature was 40 days, with less than $25 \%$ of the symptoms on bean plants after this period.

Table (1) showed that the survival time of the bean leaf (mosaic) virus active at work time (outside host cells) at room temperature $\left(25 \mathrm{C}^{\circ}\right)$

\begin{tabular}{cc} 
Symptom & Timeldays \\
\hline+ & 5 \\
+ & 15 \\
+ & 25 \\
+ & 35 \\
- & 45 \\
\hline
\end{tabular}

The appearance of symptoms(+) ..... (-) no symptoms As for Selection Point Mitigation The final Of the virus It was ( Table 4) It was Degree 5 - 10 - at Degree Concentration $\left(10^{-}\right.$ 7)

Table (2): illustrates focus squeezer the virus distance procedure series from mitigate data to pick point walt light the final

which no happen or occur then infection on plant bean

\begin{tabular}{cc} 
Symptom & Concentration \\
+ & $10^{-1}$ \\
+ & $\mathbf{1 0}^{3}$ \\
+ & $5^{-10}$ \\
- & $7^{-10}$ \\
\hline
\end{tabular}

Appearance of symptoms(+) (-) no symptoms

Table (3) the heat Inhibitory for the virus activity $45 \mathrm{c}^{\circ}$ and illustrates selection degree of the heat inhibitory for the virus activity at different heat degrees on Beans

\begin{tabular}{ll} 
Symptom & Temperature \\
\hline+ & $\dot{\boldsymbol{c}}^{\circ 25}$ \\
+ & $\dot{\boldsymbol{c}}^{\circ} 30$ \\
+ & $\dot{\boldsymbol{c}}^{\circ} 35$ \\
,-+ & $\dot{\boldsymbol{c}}^{\circ} 40$ \\
- & $\dot{\boldsymbol{c}}^{\circ} 45$ \\
\hline
\end{tabular}

Appearance of symptoms(+) ............(-) no symptoms

Transfer The Virus by the white fly insect:

Results in a table (3) suggested that the efficiency was high for white fly insect in the transfer of the virus .One insect was able to transfer the virus from the injured plant to healthy one in the rate of $25 \%$. And that is the ratio, when, Increase the number, of the Insects on the plant To reach $100 \%$ in existence of10 Insects / Plants Ghanem, et.al., 2001 . the previous results were similar to the result of our study in particular . is found that less interval needed that we found for the white fly insect on the injured plant to acquire the virus was 30 minutes, as well as, the insect carrier for the virus for events of the infection. And the Incubation period of the virus in the insect ranged between 5 - 24 hours Metho,et.aal.,1994. Similar Results were found to be agreed to the result of this study In particular, Ajlan,. 2002.

\section{DISCUSSION}

Symptoms caused by the virus included in the study, was observed to be the appearance of green dim spots or yellowing on the plant leaves, after exchange the green natural color of the plant leaves, then the symptoms appeared to be spattered pale color on the twisted plant leaves (Conti Maurizio, A. 1994 , Duffus , JE 1994)

Chlorotic spots caused by nymph feeding and disfiguration by honeydew and associated sooty moulds may be the first symptoms observed. Other symptoms like leaf curling, yellowing, mosaics or yellow-veining may indicate the presence of whitefly-transmitted viruses.These symptoms are also observed in B. tabaci infestations(Costa.et.al.1993). The feeding of adults and nymphs causes chlorotic spots to appear on the surface of the leaves. Depending on the level of infestation, these spots may coalesce turning the leaf yellow resulting in the shedding of leaves

Transmission from host to host by vectors is an tmportant step in the biological cycle of plant viruses to ensure their maintenance and survival

Transmission is often characterized by some degree of specificity and numerous findings indicate the possible involvement of a specific ligand/

receptor interaction. Extensive information is available on viral determinants of transmissibility but limited information is available on viral determinants of transmission specificity.

Van Regenmortel, MHV 1971 symptoms which caused by CMV on the beans was similar to that caused by viruses which transmitted by white fly vectors ( Conti Maurizio, A. 1994 , Duffus , JE 1994 ) ; And with that, can highlight them easily from through length of their particle , cytopathological effects, Symptoms And method of virus transmission and Infection spread by the white flies by B. tabaci to be Clear Sela , I., 1980

\section{REFERENCES}

[1] Agrios GN (2014). "Plant pathology," 5th Ed. pgs. 751 - 752, and Sanat printers Academic press: Elsevier, India.

2] Ajlan, AM (2002). Monitoring of whiteflies and thrips on greenhouse cucurbit plants using yellow sticky traps in Al- Hasa district, Saudi Arabia. J. Pest Cont. \& Environ. Sci. 10 (1 ): 1-12.

[3] Babović , M. (2003). Osnovi patologije biljaka . Poljoprivredni fakultet Univerziteta u Beogradu

[4] Bird, J .; Idris, A .; Rogan, D. and Brown, JK (2001). Introduction of the exotic logo yellow leaf curl virus- Israel in logo Puerto Rico. Plant Dis., 85: 10218- 1036.

[5] Brown, JK, Frohlich , D., and Rosell , R. 1995 The sweetpotato / silverleaf whiteflies: biotypes of Bemisia tabaci ( Genn .), or a species complex Annu . Rev. Entomol . 40 : 511-534.

[6] Chavan, JK, LS Kute, and SS Kadam. 1989. In: CRC Hand Book of World legumes. p. 223-245. DD Salunkhe and SS Kadam (eds.), Boca Raton, Florida, USA : CRC Press.

[7] Costa, AS 1986. Whitefly-transmitted diseases Annu . Rev. Phytopathol . $14: 429-449$

[8] Costa HS, Brown JK, Sivasupramaniam S, Bird J (1993) Regional distribution, insecticide resistance and reciprocal crosses between the 'A' and "B" biotypes of Besmisia tabaci. Insect Science and its Applications, 14, 127-138

[9] Duffus , JE 1994. Diseases vectored by whiteflies. Etiology, ecology, geographical distribution and possible control measures Arabian J. Plant Prot. 12: 143-147.

[10] El- Muadhidi , MA, Makkouk , KM, Kumari , SG, Maasser , J. Murad, SS Mustafa, RR and Fares T. (2001). Survey for legume and sereal viruses in Iraq. Phytopathia Mediterranea . 40 (3): 224-233. 
[11] FAO. (2006). Food and Agriculture Organization of the United Nation, Statistical Databases, Rome, Italy. <http://apps.fao.org. . .<//

[12] Francks, RIB, Milne, RG, and Hatta, T1985. Atlas of Plant Viruses, Vol. II. CRC Press, Inc. Boca Raton, FL.

[13] Ghanem , M .; Morin, S. and Czosnek , H. (2001). Rate of tomato yellow leaf curl virus translocation in the circular transmission pathway at its vector, the whitefly. Phytopathology, 91: 188- 196.

[14] Hanson, RK, \& Thornton, D. (2000). Improving risk assessment for sex offenders: A comparison of three actuarial scales Law and Human Behavior, 24, 119-136. doi: 10.1023 / A: 1005482921333.

[15] Hassan, AA, and Duffus , JE 1991. A review of a yellowing and stunting disorder of cucurbits in the United Arab Emirates. Emir J. Agric. Sci. 2: 1-16.

[16] Ismail, ID2000: Preliminary survey of legume viruses in Lattakia Province. Journal of Tishreen University for studies and scientific research, Agriculture series., 33 (9); 939-929.

[17] Jabr Khalil (1984 ). Categories And labels Viruses the plants, Enterprise the public For publication And distribution - Tripoli. P 7271 731-726

[18] Lapidot, M .; Friedmann , M .; Pilowsky , M .; Ben-Joseph, R. and Cohen, S. (2001). Effect of host plant resistance of tomato yellow leaf curl virus (TYLCV) on virus acquisition and transmission by its whitefly vector. Phytopathology, 91: 1209-1213.

[19] Liu, TX (2000). Population dynamics of Bemisia argentifolii on spring collard and relationship to yield in the lower Rio Grande Valley of Texas. J of Econ. Entomol . $93: 3,750-756$.

[20] Makkouk , KM, El- Muadhidi , MA and Kumari , SG (2001). First record of Beet western yellows virus, chickpea chlorotic dwarf virus and faba bean necrotic yellows virus affecting faba bean (Vicia faba L.) crops in Iraq. Plant Pathology, 50 (6): 793 p.

[21] Mehta, P.; Wyman , J, A .; Nakhla , MK and Maxwell DP (1994) b. Transmission of tomato yellow leaf curl virus by Bemisia tabaci ( Homoptera : Aleurodidae ). J. Econ .. Entomol ., 87 (5): 1291-1297.

[22] Morales, J. , F ; Jones, P G. (2004). The ecology and epidemiology of whitefly-transmitted viruses in Latin America. Virus Research 100 (1): 57-65.

[23] Pappu , SS; Pappu , HR; Langston, DB and Riley, GD (2000) Outbreak of tomato yellow leaf curl virus (Fam. Gemini virus) in Georgia. Plant Dis. 84: 457.

[24] Petrovic D, Ignjatov M, Nikolic Z, Vujakovic M, Vasic M, Milosevic $M$ and Ksenija $T$ (2010). Occurrence and distribution of viruses infecting the bean in Serbia. Archives of Biological Science Belgrade 62 (3) 595-601.

[25] Polston, JE and Anderson, PK 1997. The emergence of whitefly-transmitted geminiviruses in tomato in the Western Hemisphere. Plant Dis. 81: 1358-1369.

[26] Ramusi M, Flett B (2012). Transmission of maize streak virus from grasses to maize

[27] Robbins M., Kakani K., Rochon D., 1999. Evidence that fungal zoospores contain specific receptors for transmission of Cucumber necrosis virus. In: Sherwood JL, Rush CM ( eds .). Proceedings of the Fourth Symposium of the International Working Group on Plant Viruses with Fungal Vectors Denver, p. 101-104.

[28] Robertson J r., R.S. 1962. The role of seed transmission in the epidemiology of bean mosaics in Central Washington. Plant Dis. Reptr. 46:71-72.

[29] Rochon D, Kakani K., Robbins M, Reade R (2004). Molecular aspects of plant virus transmission by Olpidium and plasmodiophorid vectors. Annu . Rev. Phytopathol ., 42: 211-241.

[30] Sela I, Assouline I, Tanne E, Cohen S \& Marco S (1980) Isolation and characterization of a rod-shaped, whitefly-transmissible, DNA-containing plant virus. Phytopathology 70, 226-228.

[31] Smith, HA, Koenig, RL, McAuslane, HJ, \& McSorley , R. (2000). Effect of silver reflective mulch and a summer squash trap crop on densities of immature Bemisia argentifolii ( Homoptera : Aleyrodidae ) on organic bean Journal of Economic Entomology 93, 726-731

[32] Secker-Walker, R. H., Solomon, L. J., Flynn, B. S., Skelly, J. M., \& Mead, P. B. (1998.(Smoking relapse prevention during pregnancy. A trial of coordinated advice from physicians and individual counseling. American Journal of Preventive Medicine, 15(25 - 31).

[33] Strange RN (2003). Introduction toPlantPathologyPrnters : TJ International Ltd., Padstow , Cornwall. Great Britain, p. 75-80.

[34] Van Regenmortel , MHV 1971. Watermelon mosaic virus No.63. Descriptions of plant viruses Commonw . Mycol. Inst ./ Assoc. App Biol., Kew, Surrey, Eng.

[35] Wisler, GC, Li, RH, Liu, H.-Y., Lowry, D S., and Duffus , JE 1998. Tomato chlorosis virus : A new whitefly-transmitted, phloem limited bipartite closterovirus of tomato. Phytopathology88: 402-409.
Gazala I. F. Saad Plant Protection Department- Faculty of Agriculture- Omar AL-Moktar University, El-Beida, Libya

Mariam Saleh Mohamad Plant Protection Department- Faculty of Agriculture- Omar AL-Moktar University, El-Beida, Libya

Othman. B.H.AL-Daikh Plant Protection Department- Faculty of Agriculture- Omar AL-Moktar University, El-Beida, Libya 